Paper for WEHC Kyoto, 7 August 2015: S20041 Catching Up Now and Then: Do Historical Perspectives on Developing-Country Dynamics Still Make Sense?

\title{
IS AFRICA TOO LATE FOR 'LATE DEVELOPMENT’? GERSCHENKRON SOUTH OF THE SAHARA ${ }^{1}$
}

\author{
Gareth Austin
}

\begin{abstract}
Gerschenkron analysed the characteristics of 'late development' in terms of calibrated deviations from those of a spontaneous industrialization (modelled on his understanding of the British case). Amsden argued that catching-up was harder in the twentieth century than in the nineteenth, because the technological gap was bigger, and she doubted that the advantages of backwardness extended to countries with the schooling and literacy rates of Sub-Saharan Africa in c.1990. Many political scientists and others have doubted that African states have been and are capable of being 'developmental'. This paper is intended to present an economic historian's view of the prospects of Sub-Saharan Africa achieving a twenty-first century 'late' industrialization, drawing on - and evaluating - propositions form some of the models of economic development used by economic historians.

I argue that the Gerschenkron-Amsden tradition has valuable insights for the African case(s), such as the necessity for the state to act as the major coordinator in the industrialization of countries that start well short of having a comparative advantage in manufacturing. However, the 'late development/late industrialization' approach is best set within the Sugihara's longer-term, non-Eurocentric framework of very long-term 'paths' of development, which respond to particular factor endowments with characteristic choices of technique and institution. In this context, Africa's main path was land-extensive, seeking to maximize returns to labour rather than land. This helps explain why African states were in no position to launch their own 'late industrializations' in the late nineteenth century. It also suggests that Africa was unlikely to have moved directly from handicrafts to modern manufacturing without an intervening phase of specialization in primary product exports; which West Africans indeed embarked upon before the development of comparative advantage in such exports was reinforced and generalized by colonial rule. The earlyindependence states were not particularly successful in their import-substitution drives (partly because their factor ratios were still highly unfavourable), and the post-1995 African economic boom has been accompanied by a shrinkage in the share of manufacturing in GDP.

But Africa's resource ratios have changed radically in the last century, especially in recent decades, towards labour abundance plus much greater human capital formation. These changes were partly endogenous to the land-extensive path, an example of how human reactions to a particular 'endowment' can change it. They make it much more likely than before that industrialization, initially labour-intensive, can take off in at least some African economies, with active support and prompting by the state. Such 'developmental' states exist in Africa, though they are not necessarily the most democratic. Finally, the paper also argues that the 'broad capital' strand of endogenous growth theory captures something important in the African context, relevant both to the ultimate demise of the apartheid formula for economic growth, and to the prospects for 'late industrialization' more widely in the subcontinent.
\end{abstract}

\footnotetext{
${ }^{1}$ In this chapter, 'Africa’ means 'Sub-Saharan Africa’ unless otherwise stated. The essay is a 'thinkpiece' which should be read in conjunction with the more empirically detailed Austin 2013a and Austin, Frankema and Jerven 2015. I reviewed the 'late industrialization' literature in general comparative terms in Austin 2010. Any mistakes are mine.
} 
Alexander Gerschenkron's fundamental insight was the concept of 'late development', or (as Alice Amsden put it, more precisely) 'late industrialization', albeit without using either term himself (Gerschenkron 1962; Amsden 1992). He was not the first to notice the existence of late-comer advantages (Van der Linden 2012: 561-2). But he was perhaps the first to consider systematically how the industrialization of even one country altered the circumstances affecting possible future industrializations elsewhere: not only by creating a competitive challenge and, on the other hand, the opportunity to borrow industrial technology, but also by changing the incentives to rulers. The military risks of not industrializing were frightening for empires facing the possible loss of great-power status (Russia) or even independence (Japan) in the late nineteenth century. The general conclusion of Gerschenkron's work was that the process of industrialization - its motors, form and timing - would be different in late-comers. The policy implication was that late-comers did not need to wait until they had spontaneously accumulated all the prerequisites for $a b$ initio industrialization; nor could do they afford to do. Rather, they could and should find 'substitutes' for any missing prerequisites. Elaborating his approach, Gerschenkron (1962) coined the term 'relative backwardness', as the key to a framework for analysing later industrializations as calibrated deviations from the requirements of spontaneous industrialization.

Those requirements included, for instance, 'an expanded' market for manufactures based 'on the rising productivity of agricultural labor' (Gerschenkron 1962: 354). The more a country lacked such requirements, the greater its need to 'substitute' for them in the course of a deliberate industrialization. A key aspect of this was that, the more backward the economy, the more likely that it was that its industrialization would 'proceed under some organized direction', to supply more 'capital to the nascent industries' and 'provide them with less decentralized and better informed entrepreneurial guidance’ (Gerschenkron 1962: 44, 354). Further, the greater the extent of deviations from a spontaneous industrialization, the greater the likelihood that the organizational substitute for the market as the coordinator of industrialization would be, not an group of private actors (cartelistic investment banks, in his interpretation of the German case) but, rather, the state (Gerschenkron 1962).

Defining late industrialization simply as industrialization with borrowed technology, Amsden sought to adjust Gerschenkron's insight to the twentieth century. As the spread of industrialization proceeded, the technological gap between the industrialized countries and the rest had become bigger, and was now increasingly protected by the construction of an international law of intellectual property (Amsden 1992). She enlarged on the guiding role of the state in late industrialization, which required 'getting prices wrong' (Amsden 1989; also Wade 1990).

Gerschenkron did not try to apply his analysis beyond Europe, because it was outside his own comparative advantage (Gerschenkron 1962: 7n). Amsden, following her influential study of 'late industrialization' in South Korea (Amsden 1989), went on to present arguments that appeared to leave little prospect of Africa joining the otherwise growing industrial and developmental catch-up club. Specifically, she maintained that the possibilities for successful 'substitution' were limited to countries which, while 'relatively backward' in Gerschenkron's terms, were so only up to a point. In Amsden's view, countries that lacked relatively high levels of education, and therefore 'human capital', would be unable to take-off industrially in a world in which the advantage of cheap labour had been neutralized by a combination of labour-saving technology and segmented labour markets, the latter allowing rich countries to exploit pools of cheap (typically immigrant) labour within their own economies (Amsden 1992, 2001). There is also an argument that African industrialists are much too late to be able to exploit labour in the harsh ways open to earlier industrializers - with unions repressed, voting rights restricted or absent, and no sick pay or overtime let alone pensions (O. F. Onoge 
in 1974). ${ }^{2}$ What happened for a time during the industrializations of Britain, Germany and the USA, and indeed in segregationist and apartheid South Africa (Trapido 1971), may now be unacceptable to consumers and lenders from some of those same countries, and to African electorates. Meanwhile, recent national-accounting work in comparative economic history has shown that countries that develop manufacturing sectors have generally experienced faster growth in manufacturing output than the early industrializers: Agustín Bénétrix, Kevin O’Rourke and Jeffrey Williamson (2014) report 'unconditional convergence' of followers on leaders since the 1870s. But this has yet to be replicated south of the Sahara (Austin, Frankema and Jerven 2014). Even with the recent economic GDP growth, averaging about 2 per cent per year since 1995, there has been no industrial breakthrough. According to the United Nations Economic Commission for Africa, the share of manufacturing value-added in GDP actually declined in Sub-Saharan Africa, from 16.6 per cent in 1980 to 12.7 per cent in 2009 (UNECA 2013: 74). ${ }^{3}$

This paper asks whether Africa is too late to catch up the existing industrialized countries: whether because, as Amsden might have said, it lacks the conditions necessary to adopt and use borrowed technology to its full potential; or because, to use Gerschenkron's terminology with more explicit pessimism than he did, the 'substitutions' that African countries can now make for missing prerequisites of spontaneous industrialization are insufficient for catching up the industrialized countries when the technological gap seems so wide and apparently so unfavourable for bridging by the means available in Africa.

The discussion that follows is organized in five sections. The first draws attention to some of the other historical perspectives on the dynamics of contemporary developing economies, besides the Gerschenkronian tradition. Particularly important among these is the notion of very long-term paths of technical and institutional choice, responding to - and gradually changing - particular kinds of factor endowments. Section 2 is devoted to clarifying the problem, in that I argue that African 'late development' does indeed require industrialization, at least of several of the larger African economies. Section 3 outlines the main path of economic development pursued in Africa during c1500-c1900, which, for most of the continent, was the last four centuries before colonization. I describe this path as 'landextensive', and seek to specify the major reasons, economic and political-economic, why it was unlikely to lead to industrialization. Section 4 considers the colonial and post-colonial periods, focussing on the eventual, if so far incomplete and continuing, transition towards land scarcity and, in response, to a path of development that is more intensive in labour, capital, and human capital terms. The conclusion, Section 5, reflects on the possibilities for 'substitution' strategies and practices in the pursuit of 'late development' over the next generation.

\section{Long-term 'paths' and other historical perspectives}

The historical perspectives pertinent to the analysis of contemporary late-development are not limited to substitution and the state, important as they are. Three other issues seem to me

\footnotetext{
${ }^{2} \mathrm{O}$. F. Onoge, 'The indigenisation decree and economic independence: another piece of bourgeois utopianism', in Nigerian Economic Society, Nigeria's Indigenisation Policy: Proceedings of the November 1974 Symposium (Ibadan, n.d.), quoted in Iliffe 1983: 85.

${ }^{3}$ While rising slightly in North Africa, from 12.6 to 13.6\% (UNECA 2013: 74). Earlier in the report it is stated that the share of manufacturing in aggregate output in the continent as a whole fell from over $12 \%$ to around 11\% during 1980-2010 (p. 7). The apparent discrepancy is not commented upon, and the 'statistical note' (p. 252) is vague. What is clear, however, is that while manufacturing output has risen in absolute terms, the structural trend is in the wrong direction for industrialization.
} 
particularly pertinent. ${ }^{4}$ One is the role of institutions, the rules surrounding economic activity, which in recent decades have received particular emphasis within the rational-choice tradition (cf. North 1990). Because this has received huge attention in relation to economic development on a global scale, and because I have expressed elsewhere some major reservations about aspects of rational-choice institutionalism in economic history (Austin 2008b; following a mixed verdict in Austin 2005), I will keep the present discussion of this very important perspective brief. There is a very influential argument that the kind of rules about political power and individual property rights which obtain in the richest of the industrialized countries today are optimal for the economic development of the rest of the world. Not only are such views strongly put in the academy (Acemoglu, Johnson and Robinson 2001, 2002; Acemoglu and Johnson 2012), they are also frequently (if, understandably, more crudely) stated when politicians in rich democracies speak on world development. Briefly, in my view, this confuses process and (frequent, though not inevitable) outcome. Democracy as it is understood today (based on one person one vote and freedom of speech and protest) has simply been not the norm during industrializations to date (Trapido 1971; Chang 2002). Again, that secure private property rights is essential for economic takeoff is contradicted by the experience of the USSR and, more recently, China (Clarke, Murrell and Whiting 2008).

The second issue is the lessons, if any, to be learned for 'late development' in Asia, Africa and Latin America from the experience of 'catch-up growth' within the 'First World'. This is not about initial industrial take-off, as had either happened or was well under way in most of western Europe and in North America and Japan by the late nineteenth century. Rather, it is about the jockeying among the club of leading industrial countries since then, focussing on how the USA, after overtaking the UK by the First World War, established a very strong lead in total factor productivity, and how far, when, and why, countries in western Europe eroded that lead after the Second World War. This debate has produced ideas pertinent to the rest of the world, such as the notion of 'technological congruence', denoting the extent to which a particular technology fits both the supply and demand sides of the economic context in which it is introduced (Abramovitz and David 1996). Historians of industrialized economies have also provided growth economists with much to inspire them concerning models of endogenous economic growth, especially those which seek directly to explain growth in total factor productivity, rather than subsuming it under increased investment, whether narrow (physical capital) or broad (including human capital) (Crafts 1997). This is useful for the analysis of how late-developing economies sustain, or fail to sustain, economic expansion from 'extensive' growth (based on increased factor inputs) to 'intensive' growth (based on rising total factor productivity). But it is not so relevant to the problem of how an economy takes off in the first place, in a world in which others have already done so, creating a context in which take-off requires adoption and adaptation, but not necessarily invention.

The third issue is factor endowments, and especially human reactions to them. Recently, Kaoru Sugihara (2003, 2007, 2013) has developed a framework for analysing the dynamics of economic development that differs fundamentally from Gerschenkron and Amsden. Rather than seeing the British Industrial Revolution as the original pattern from which later industrializations deviate, Sugihara distinguished different 'paths' of long-term development, each defined by a distinctive factor-bias in choices of technique and institution, and followed as far as possible before and during industrialization. Thus, whereas British industrialization was part of a 'capital-intensive path', Japan industrialized within a 'labourintensive path’. Whereas Gerschenkron thought late-industrialization more capital-intensive

\footnotetext{
${ }^{4}$ My approach is from economic history. For an important assessment from economic sociology, bearing particularly on the first two issues identified here, see Schrank (forthcoming, 2015).
} 
than early-industrialization, in Meiji Japan the textile industry responded to the comparatively high cost of capital and low cost of labour by opting for second-hand machines, with wooden rather than metal frames, and worked twenty-four hours a day (Sugihara 2003, 2007). Compared to (or alongside) the 'late development' tradition initiated by Gerschenkron, Sugihara's 'paths' framework has the attractions for historians of taking a longer view, of recognizing the polycentric character of global economic history before the nineteenth century, and of highlighting the distinctiveness of technical and institutional responses in different societies to relatively persistent differences in resource endowments: a pattern of dynamic difference that formed the context in which they faced the political threat and the total challenge (economic, technical, social, cultural) of the beginning of industrialization elsewhere. ${ }^{5}$ Africa, however, did not fit either of Sugihara's original two paths, 'capitalintensive' and 'labour-intensive': not only was and is it short of capital, but historically it has been short of labour in relation to land (Hopkins 1973, Austin 2008a). But the 'plural paths' framework is flexible enough to accommodate a 'land-extensive' path (Austin 2013a, b) which, as we will see later, is much more congruent with African history.

\section{The place of manufacturing in African 'late development'}

Despite the generally disappointing contribution of manufacturing to Africa's economic expansion over the last twenty years, it seems inconceivable that Africa can catch up the OECD members in average living standards without major growth in this sector, including the industrialization of at least some of the larger African countries. The spatial distribution of manufacturing is often very uneven within a region, which may reflect specialization by comparative advantage. Conversely, the lack of such specialization within Africa to date is itself a major symptom of 'under-development'. The UNECA states that intra-African trade is already 'dominated by industrial products', but notes that such trade is still only 10-12 per cent of the trade of the African continent (UNECA 2013: 46). Again, the need to turn commodity-based growth into what policy-makers currently call 'structural transformation', notably including manufacturing, is not only because of the familiar observations that productivity tends to be higher in manufacturing than in agriculture, that mineral deposits are finite, and that demand for beverage crops is not very elastic.

Africa needs more manufacturing also - paradoxical as this may seem - because of environmental constraints on extraction and agriculture. These are multiple. If the major fossil-fuel-using world regions eventually act to mitigate climate change, the market for oil and gas will be reduced and part of Africa's potential fossil-fuel exports would almost certainly remain underground. More fundamentally, Africa needs a ‘Green Revolution', but the reason why (with a few exceptions) it has not happened already is partly because many soils in Sub-Saharan Africa are either low in fertility or fertile but easily eroded (Vanlauwe et al. 2002, especially Mokwunye and Bationo 2002: 209-11; Breman 2012). Agriculture is necessarily water-intensive, and high-yielding varieties of seed are even more so. Africa is the most arid of the continents, and with the Intergovernmental Panel on Climate Change forecasting greater aridity for Africa in future (IPCC 2014), this is a major problem, making it all the more doubtful that Africa's future comparative advantage lies in agriculture, some countries probably excepted. Desalination is fossil-fuel intensive; as are chemical fertilisers, and more experimentation and additional investments in the soils are needed before fertilisers become as effective in Africa as they have been in some other areas (Breman 2012; further, Vanlauwe et al. 2002). ${ }^{6}$ Services will play a part, but largely as a function of the growth of

\footnotetext{
${ }^{5}$ I discuss Sugihara's 'paths' thesis, in the light of further work by himself and others, in Austin $2013 \mathrm{~b}$.

${ }^{6}$ I discuss this in historical context, and in more detail, in Austin forthcoming, 2016b.
} 
manufacturing. For example, without such growth, Africa - in the same time zones as London and Frankfurt - is literally not well placed to export financial services, though Johannesburg and younger financial centres in Africa may be expected to increase their share of the African market(s). In this context, ironically but not perversely, there is a stronger case for more manufacturing south of the Sahara, especially if it takes advantage of the region's existing and warming - environment to power it in large part by solar energy. Moreover, with Africa's historic share in greenhouse gas emissions having been relatively tiny, its governments can justly argue that it is the responsibility of the existing industrialized countries to make a little space for the late-comers. So, while individual countries may join the club of 'developed' economies without industrializing, a general African catch-up will surely involve - and require - the industrialization of enough countries within the region to provide a motor for the rest.

Given the pessimism of Amsden and others, however, the question is whether such an ambition is even remotely realistic: is the technological gap between the current industrial leaders and the poorest region on earth now too great to be closed, do political conditions internationally and domestically fatally inhibit the required 'substitutions' anyway, and does Africa have sufficient late-comer or other advantages to give it a real chance? The startingpoint for any plausible answer must be an examination of why there has not been an industrial revolution in Africa already, and whether economic and political circumstances have been changing in ways that make an African 'late industrialization' more or less feasible.

\section{The 'land-extensive' path of development in late pre-colonial Africa, c1500-c1890}

The speed and extent to which African countries could participate in the global spread of industrialization since the late eighteenth century depended on both economic and political conditions. In Gerschenkronian terms, their economic situations would determine the extent and form of 'substitutions' for the 'prerequisites' of spontaneous industrialization that would be needed for 'late industrialization'; while political, and political economic, conditions would greatly affect the capacity and willingness of the state to do whatever was necessary to bring the substitutions about. Vast and varied as Africa is, certain generalizations may be made, with appropriate qualifications.

Until the twentieth century, at least, at any given time most of the continent south of the Sahara was relatively short of labour as well as capital, at least in agriculture (as of 1800, the kingdom of Abyssinia - northern Ethiopia - was the biggest exception). However, land abundance did not mean resource wealth. Many of the mineral deposits that have contributed to export growth in recent decades were not valuable until markets for them were created by inventions during industrialization elsewhere: from rubber tyres to mobile phones. Transport costs were high because of the relative rarity of navigable rivers and the prevalence, in the forests and much of the savannahs of tropical Africa, of sleeping sickness, whose principal economic effect was to kill large animals, thereby preventing their use in transport or farming over wide areas. Exploitation of the land surplus was further constrained by other features of the environment, such as soils that were often infertile and, where fertile, thin and easily leached; and extreme seasonality in the distribution of rainfall, which in many areas precluded productive use of the land during the heart of the dry season. In this setting, agricultural methods were aimed at maximizing returns to labour rather than yield per hectare. Landextensiveness was the characteristic approach both in arable and pastoral economies: in the former, extended forms of land rotation plus avoidance of clear felling; in the latter, transhumance. Over centuries, despite local histories of irrigation, terracing and ploughing where necessary or possible, the main source of higher productivity and improved food 
security was the selective adoption of new crops and crop varieties, from Asia and (from the sixteenth century onwards) the Americas. Some of these adoptions also permitted more efficient use of the dry season, where they could be used to extend the agricultural year, via irrigation or in harvesting. Otherwise, the opportunity cost of dry season labour was often very low, with the paradoxical effect - in an otherwise labour-scarce region - of facilitating low labour-productivity activities such as narrow-loom weaving (by choice) as well as headloading (by necessity) (Austin 2008a).

Given the incentives to self-sufficiency presented by land abundance and high transport costs, responsiveness to market incentives was remarkably high, notably in early modern West Africa (Hopkins 1973; Austin 2012). There a major component of imports from the Atlantic trade was currency materials such as cowries. As Joseph Inikori has pointed out, these were not accepted back by European merchants, so it must be assumed that they were imported to lubricate intra-African trade (Inikori 2007). The gradual adoption of cowries plus (for high-value exchanges) gold dust as the currency system over much of West Africa can be seen as a process of institutional reform that reduced transaction costs. The initiative for this apparently came from African merchant networks, rather than from states (Austin, forthcoming).

In these settings, it was generally difficult to secure the fiscal foundations for state building. Abyssinia was founded on an agricultural surplus, extracted via tribute from peasants (Crummey 1980). Elsewhere states were more commonly based on locational rents (taxing trade), or resource rents (control of gold mines). As with intensive agriculture, statebuilding is ancient in Africa, but stateless societies and mini-states remained common on the eve of the European partition of the continent, which occurred between 1879 and about 1900 (Goody 1971; Law 1978; Herbst 2000).

Another institutional response to the abundance of (usually not very fertile) land was inheritance systems that tended not to concentrate but rather to spread wealth, favouring the accumulation of allies and clients (Goody 1976), though in some cases these systems were to become narrower where and when land became scarce in the twentieth century (Bates 1990). Another response was the use of coercion to reduce the supply cost of labour. For instance, a growth of commodity production for internal and external markets stimulated a major increase in the importation of slaves by many societies in East and West Africa in the nineteenth century. While no economic explanation for any form of forced labour can ever be sufficient, the private profitability of labour coercion is indispensable to accounting for the growth of slavery within Africa, especially in the nineteenth century (Austin, forthcoming 2016a).

Throughout this era, slaves were exported from Sub-Saharan Africa on a scale which can only have reinforced the structural problem of low population density. Some 13 million captives were embarked in the Atlantic trade, from the fifteenth century to 1867; guesstimates put the Saharan, Red Sea and Indian Ocean trades at a combined total of over 5.8 million for 1500-1900 (Lovejoy 2012: 46, 138). The durability and scale of the trade suggest that the labour productivity of enslaved Africans was higher in the regions to which they were forcibly taken than in those from which they were exported (rather than sold to African slaveowners, which also happened, and increasingly from the late eighteenth century). Part of the difference may be exchange value (proximity to the markets for slave-produced goods and services), but part of it presumably reflected constraints on labour productivity within SubSaharan Africa, which can indeed be accounted for by the environmental obstacles (Manning 1990: 33-4; Austin 2008a, 2008b). Again, an economic explanation is insufficient, in this case for an activity which, however profitable for the sellers as well as the buyers, involved immense external costs for the wider region including collateral deaths and injuries, destruction of property, and general insecurity within a political economy that rewarded 
militarism. This extreme free-riding was encouraged by the rarity of huge states and the widespread political fragmentation (Inikori 2003). Whether or not the external slave trades produced an aggregate fall in the population south of the Sahara, or simply slowed its growth, the loss of so many people can only have reinforced the underlying problems of labour scarcity and small markets.

In these circumstances, despite certain economic advances during the sixteenth to nineteenth centuries, African economies in the eighteenth and nineteenth centuries lacked many of Gerschenkron's 'pre-requisites' for spontaneous industrialization, such as expanding markets for industrial goods based on rising labour productivity in agriculture, not to mention very low rates of modern schooling. Moreover, African states were in an extremely weak position in the face of the existential threat from European imperialism towards the end of the nineteenth century, reinforced as it was in both logistics and military technology by industrialization. One of the reasons why most of Africa was finally colonized then - so late in the history of European overseas expansion - was that industrialization, plus the adoption of quinine against malaria, had greatly reduced the cost of conquest in Africa for European states. Some of the stronger African states tried to import specific industrial technologies, including the telegraph, while mission-educated African elites on the West coast vainly sought a modernization under European over-rule but with some sort of African autonomy. But only the most fiscally powerful African polity, Abyssinia, was able not only to defeat a full-scale invasion, but also to expand its own empire (to incorporate what is now southern Ethiopia) and establish itself, at least pre-Mussolini, as a political and business partner for Europe. Even Abyssinia/Ethiopia - with its long indigenous history of agricultural surpluses and Christianity, the latter entailing at least elite literacy - did not set out to match Meiji Japan's feat of 'late industrialization' in the face of Western imperialism.

\section{From land-extensiveness to modern manufacturing? The colonial period, c.1890- c.1960}

The incoming colonial administrations, established mainly during the 1880s-1900s, promoted primary product exports not manufacturing. This was partly out of necessity: their political masters in Europe generally demanded that they make the colonies fiscally self-sufficient as soon as possible. To this end, they needed to raise revenue, and the obvious way to do this was to induce higher export earnings, which they could tax, directly or indirectly, more easily than any other potentially sizable source of income. Agriculture and mining were the only sectors in which this seemed feasible. As before colonization, revenue-raising in Africa was largely a function of access to locational and resource rents (Austin 2006; Frankema and van Waijenburg 2015): having soils suitable for growing export crops in an area from which railway or road-distance to the coast was relatively small was a huge help (Ghana, to a lesser extent Senegal), as was the presence of mineral wealth (South Africa, to a lesser extent the Belgian Congo with its copper-rich province of Katanga). Colonial officials were also aware of calls from manufacturing interests back home that the colonies should be made to generate raw materials, notably cotton, to reduce metropolitan manufacturers' costs, and to secure their supplies. Such calls were given organized amplification by groups such as the British Cotton Growers' Association (founded in 1902). But the boot was often on the other foot: colonial administrators also sought buyers, and in some cases (notably Kenya) settlers, from the metropole in the hope that they would increase the taxable output of the economy. In the event, colonial governments in Africa, like the African states that preceded them, managed to extract only relatively modest tax revenues from their subjects (Gardner 2012). Ewout Frankema calculated that, excluding customs duties, on average, the number of days of 
unskilled wage work required to match the government revenue per capita was 1 day a year in Nigeria in 1911, and still 1 day in 1929 and 1937. Nigeria was an extreme case, but was also the most populous colony on the continent. At the opposite extreme, among British colonies, was the quasi-settler colony of Kenya, where the figure rose from 5 days in 1911 to 11 in 1929 and 13 in 1937 (Frankema 2010: 465-6). As a result, they could afford only modest bureaucracies. In the 1930s the ratio of whites employed by the colonial administration to the population they sought to rule was 1: 27,000 in French West Africa, 1: 35,000 in the Congo, and 1: 54,000 in Nigeria, 1: 27,000 in French West Africa, and 1: 19,000 in Kenya (KirkGreene 1980: 35, 39). Actually, the ratios were even lower than that, because the population censuses were usually significantly under-counted, precisely because of the limited administrative capacity (Manning 2010; Frankema and Jerven 2014).

Thus colonial regimes in Africa were generally lacking in the capacities to be ambitious 'developmental states' on the Gerschenkron-Amsden model, even had they wished to be. The biggest financial advantage that the colonial regimes had over the African polities they had annexed was their ability to borrow large sums on the European bond markets, often specifically to finance the construction of railways and ports, thus deepening the infrastructure of the export-import economies. But this did not mean that they had the option of using loans to finance infant industries, had they wished to do so. Their ability to borrow was subject to control from the imperial treasuries, who expected loans to be repaid with interest and on time: which would have been unlikely in a sector in which African economies lacked comparative advantage, and would no doubt have elicited outrage from metropolitan manufacturers with whom colonial industries would be competing (cf. Brett 1973). In Africa, colonial administrations in Africa lacked the political legitimacy and economic opportunity that enabled the elected governments of Australia, Canada and New Zealand to tax and borrow on the kind of scale required for the state to make a really powerful and sustained difference to human capital formation and other investments in long-term economic development (Accominotti, Flandreau, Rezzik and Zumer 2010; Frankema 2012; Frankema and van Waijenburg 2015).

But three major qualifications or complications should be added about manufacturing and colonial rule.

\section{Sources of specialization in primary-product exports}

First, in Africa, the colonial-era specialization in farming and digging for export was not simply imposed by the alien rulers. Even in West Africa, which had the most substantial indigenous cotton textiles industry, the factor endowment of the time, by favouring landextensive activities, meant that a direct transition from artisanal handicrafts to modern manufacturing (defined by reliance on inanimate sources of energy) was unlikely even without colonial rule. It was much more probable that any industrialization would be preceded by a phase of specialization in the kind of products suited to a labour-scarce environment in which cultivable land was relatively abundant but also relatively highly susceptible to overuse. Such a phase occurred when the industrial revolution created new markets for agricultural products that could be profitably grown by land-extensive methods in African conditions (Austin 2013). This had already begun before colonial rule, on the west coast during the early nineteenth century, following the beginning of the abolition of the Atlantic slave trade, with peanuts and palm oil becoming the major exports (Hopkins 1973; Law 1995). Even under European occupation, Africans retained much of the initiative in the development of agricultural exporting, being responsible for the origins of cocoa-growing in Nigeria, and having the main role in Ghana's dramatic shift from exporting no cocoa beans in 1892 to overtaking Brazil as the world's biggest cocoa exporter less than twenty years later (Hopkins 1978; Hill 1997). The combination of continued labour scarcity, the (gradual) 
abolition of slavery, and the greatly increased exchange value of agricultural output, resulted in relatively high real wages for unskilled labourers in the capitals of Ghana and Nigeria (and, as these were nationally and regionally integrated labour markets, not only in the cities). They were not only well above global pre-industrial norms, but were also above those of, for example, the major textile-producing centres of British India, especially before 1940 (Frankema and van Waijenburg 2012).

The land-extensive character of West African agricultural export production was epitomized by the fact that in the nineteenth century, in parts of the palm oil exporting belt, palm trees were not deliberately planted. Again, when cocoa growing was adopted (in the limited areas where rain and soil conditions suited it), while the planting of the trees necessarily constituted an intensification (more labour per hectare, creating a fixed capital stock), African farmers' approach continued to be land-extensive rather than labour and/or capital-intensive: seeking to maximize returns to labour by bringing more land under cultivation, rather than concentrating on raising returns per unit area. This was clear not only in their planting strategy but also in their method for dealing with capsid infestation: they found that temporary abandonment worked better than pesticides). In Ghana, these methods enabled them to defeat the more capital and labour-intensive approach of European planters (Austin 1996b, 2005).

Meanwhile, in a number of colonies across the continent colonial regimes tried various forms of coercion in the course of their attempts to induce savannah farmers to expand their existing output of raw cotton, but coercion usually produced very limited results - and in Mali, as late as 1948-9, French merchants were outbid for almost the whole of the cotton crop by African brokers supplying the local handloom industry (Roberts 1992, especially p. 283). In contrast, the most successful agricultural export industries of the period developed without any direct taxation, let alone explicit coercion: cocoa cultivation in Ghana and southwest Nigeria. In short, the colonial governments' promotion of primary export production was often misdirected and frequently (though far from always) coercive. But Africans had already begun to develop a comparative advantage in agricultural exports before the colonial occupation, and where that comparative advantage was deepened, it was often by African rather than European initiative. What is often called the 'colonial division of labour', whereby Africans specialized in primary exports, is to that extent a misnomer. Though promoted and reinforced by European rulers, it also reflected the factor endowment of the Sub-Saharan subcontinent, and was rationally recognized and originated as such by Africans.

\section{Settler states and import-substitution industrialization}

The second complication to the observation that colonial regimes promoted primary exports not manufacturing is the adoption of policies of import-substitution industrialization by the two self-governing settler regimes, South Africa and Southern Rhodesia. The former became independent, as a 'dominion' within the British empire, in 1910; the latter moved from chartered-company rule to autonomy under a parliament elected by settlers, in 1923 . What made it possible for them to adopt ISI was precisely that in these cases the governments were controlled by local interests, albeit white minority ones, which differed from those of the imperial government in London.

In both cases the coercive power of the state had been deployed already to drive down the reservation wages of black labour. Specifically, both states tried to drive Africans out of the produce market and into the labour market, by large-scale appropriations of land for the use of Europeans, coupled with bans on Africans working on European farms as tenants rather than labourers. Though African production for the market proved remarkably resilient in Southern Rhodesia, in both cases the policy was successful in driving down the real wages of African employees. Without it, the South African gold mining industry could have been 
grown to only a small fraction of the size it reached by the early 1930s, when the gold price shot up following the British and United States abandonment of the gold standard (Feinstein 2005: 109-12). With mining royalties boosted by cheap labour, both governments embarked on import-substitution industrialization, South Africa in 1924 and - partly in response Southern Rhodesia in 1933 (Phimister 2000), based on electrification and including iron and steel.

The settler regimes were inferior to at least the more prosperous of the 'peasant' colonies when it came to the welfare of the black majorities (measured by both real wages and infant mortality (Bowden, Chiripanhura and Mosley 2008). But when it came to structural transformation of the economy, because they had domestic electorates to answer to - small in number and privileged in wealth and status though they were - the 'settler' governments were more 'developmental' than the administrators of 'peasant' and 'concession' colonies. The South African move responded to the demands of white workers for jobs, and of Afrikaner nationalists for economic independence from Britain; the Rhodesian response asserted the desire for economic independence from South Africa as well as a longer-term interest in developing the economy. In 1960, when most of French Africa and the largest Belgian and British colonies all became independent, manufacturing as a share of GDP was estimated at just over 20 per cent in South Africa (Lipton 1986: 402) and 16 per cent in Southern Rhodesia, whereas the 'peasant' (or, in part, indigenous rural capitalist) colony with the largest economy, Nigeria, and the one with the highest income per head, Ghana (independent in 1957), had manufacturing shares of only $4.5 \%$ and $6.3 \%$ per cent respectively (Kilby 1975: 472).

\section{'Late colonialism': imperial governments and 'development'}

Twentieth-century colonial regimes were not always indifferent, let alone hostile, to manufacturing. Even while Britain was still committed to laissez-faire, pressure from nationalists led to beginning of infant industry protection in India, in 1924 (Dewey 1978). In Southeast and East Asia, European as well as Japanese and American colonial administrations promoted manufacturing in the 1930s as a counter to the Great Depression (Brown 1997: 20315; Booth 2007). The story was different in Africa. In the 1940s, the British Colonial Office wanted to promote manufacturing in African colonies to counter the instability of primary product markets, but was largely thwarted by a more powerful ministry, the Treasury, which worried about loss of British export markets and the cost of subsidising probably unprofitable industries (Butler 1997). Meanwhile, the French government's promotion of imperial autarky had facilitated the relocation of part of the French textile industry to Hanoi, but Paris intervened to limit the equivalent growth of peanut oil processing in Senegal (Boone 1992: 47-9). In the last decade before the independence of Senegal and Nigeria (1960), there was a rush of European investment in manufacturing in tropical Africa. This was largely driven, not by the state, but by European trading companies anxious to retain after Independence their shares of markets for manufactured consumer goods that had been expanded by population growth and higher incomes from agricultural exports (Kilby 1975).

Even so, the combination of 'developmental' rhetoric from the postwar colonial governments with the success of nationalist parties bequeathed to the governments of newlyindependent Africa a mandate, and an expectation, that they would vigorously promote development. The outgoing colonial regimes also passed on the most effective mechanism yet devised for the taxation of agriculture, and thus for the 'socialisation of savings', in tropical Africa: the statutory export marketing board, which enjoyed a legal monopoly of exporting crops, and - though created in the 1930s to support rather than reduce producer prices - was able to fix the producer prices well below world market prices. This enabled the marketing 
boards to deliver a big surplus to the state. For politicians such as Kwame Nkrumah in Ghana, this seemed to be the instrument which could make possible serious industrial investment.

\section{The 'developmental state' and shifting resource ratios, since 1960}

Most of Africa recovered independence, packaged in new 'nation-states', in or about 1960 (the Portuguese colonies followed in 1975). Besides the domestic imperative to pursue development, this was the period of maximum policy influence for the advocates of active state intervention in, and even substitution for, the market, in the cause of industrialization: from Raúl Prebisch, Albert Hirschman and, indeed, Gerschenkron. One way of looking at state-led 'late industrialization' is as an attempt to shift the country's comparative advantage higher up the value scale. The question was and is whether the distance to be travelled was and is simply too great in economic terms, and whether the political commitment was sufficiently strong, in will and capacity.

Virtually all African states proclaimed some form of state-led development policy, including the promotion of manufacturing. The results were largely discredited by the 1980s, with the developmental state being reinterpreted as a rentier state. A damming assessment was given in what became the World Bank's manifesto for Structural Adjustment in Africa, the Berg Report (World Bank 1981): a verdict which has largely stuck ever since. ${ }^{7}$ In retrospect, rather than in the context of the high expectations of the decolonization era, this pessimism is somewhat exaggerated, especially considering that the countries' populations were growing at 2-4\% a year, making any per capita growth at least moderately impressive. From 1960 until the 1973 OPEC oil shock (and even for a couple of years afterwards) the average growth per capita of Sub-Saharan Africa as a whole approached 1\% per annum. Moreover, a number of countries achieved a significant expansion of manufacturing, albeit from a very low base (Sender and Smith 1986: 94-9). As of 1982, those whose manufacturing sectors accounted for at least a tenth of GDP included Kenya (13\%), Côte d'Ivoire (12\%) and Ethiopia (11\%); though not Tanzania (9\%), Nigeria (6\%) and Ghana (5\%) (Sender and Smith 1986: 96, citing World Bank data). It should also be noted that the long-term development policies of these new, under-resourced states were (and are) particularly vulnerable to disruption from the kind of short-term fluctuations, frequently of external origin, that often preoccupy the finance ministers of richer countries (Fahnbulleh 2005). As Thandika Mkandawire commented:

If a developmental state is not [to] be deified into some kind of omnipotent and omniscient leviathan that always gets what it wants, then the definition must include situations in which exogenous structural dynamic and unforeseen factors can torpedo genuine developmental commitments and efforts by the state, as happened recently [1997] in some of the most successful Asian developmental states. (Mkandawire 2001: 291)

Meanwhile, the fiscally and administratively strongest state south of the Sahara, South Africa, continued to preside over fairly rapid expansion of manufacturing, with tariff protection, in the 1950s-70s.

It is crucial to note that there was a wide range of variation in the performance of different countries. In several of the larger ones, the effect of economic policies was obscured by civil wars or independence wars during parts of the period (including Sudan, Ethiopia, the former Belgian Congo, Nigeria, Mozambique and Angola). A pattern that emerges from the other cases is that the states which made relatively modest economic interventions presided

\footnotetext{
${ }^{7}$ A useful, nuanced, analysis is Mytelka 1989.
} 
over more growth of both output and manufacturing than their neighbours who intervened more heavily (Côte d'Ivoire and Kenya compared to Ghana and Tanzania, for example) (Austin, Frankema and Jerven 2015). In other words, those which sought to diversify around export agriculture, sustaining the latter by keeping the rate of taxation of export growers low enough to give them an incentive to reinvest, did better than those who taxed export agriculture at penal rates, thereby undermining the sector whose surpluses had made (limited) state developmentalism possible (Austin 1996a). To ignore one’s existing comparative advantage completely was perilous.

The 1980s saw almost all African states adopt World Bank and IMF-sponsored 'Structural Adjustment' programmes: in most cases not so much because of external debt (very few had been considered credit-worthy enough to qualify for loans from commercial banks) as because of internal fiscal crises, especially where (as in Ghana, Tanzania and other tropical African countries outside the franc zone) state intervention had included price controls which, by the late 1970s/early 1980s, were so severe as to lead to widespread bypassing of official markets. Structural Adjustment consisted essentially in the replacement of administrative mechanisms of resource allocation by markets. Adopting such a programme therefore entailed renouncing the developmental state as understood by Gerschenkron, Hirschman and Amsden, in favour of the Douglass North version: a state strong enough to enforce private property rights and other rules of the market, and limited itself to that. Industrialization as a target in itself was off the agenda; the international financial institutions prodded African countries to focus on their existing areas of comparative advantage, in extraction and agriculture.

With dramatic exceptions, the initial results of Structural Adjustment were poor: coinciding with a decline in world commodity prices, the first 10-15 years of economic liberalization saw stagnation or actual decline in most African economies. In aggregate, according to World Bank data, the decline in GDP per capita in Sub-Saharan Africa began in 1977, several years before the introduction of Structural Adjustment, and continued until 1994: Stiglitz, Lin, Monga and Patel 2013: 12). Again, however, initial economic performance during 'adjustment' varied: amidst the cases of decline or stagnation, Ghana and Uganda recovered rapidly from preceding periods of economic shrinkage (associated in Uganda with prolonged internal violence). The liberal economic regimes introduced by Structural Adjustment have remained very largely in place to the time of writing. Since c.1995, during a period of mostly rising or buoyant world commodity prices, Sub-Saharan Africa has experienced probably its most widespread economic boom ever. If economic liberalization is blamed (credibly, only in part) for the widespread debacle of its first decade, by the same token it must be credited with part of the credit for the economic expansion during the following twenty years. But, as noted in the introduction, while manufacturing output has risen in absolute terms, as a share of output it was lower in 2009 (and probably still today) than in 1980. This is hardly a secure route to joining the club of rich nations.

So, the case for states to intervene to promote manufacturing in Africa, reversing and going way beyond its recent relative decline, is urgent. Yet doubts about the chances of success abound: external and internal, political and economic. These include the strength of competition from the current 'workshop of the world', China; the restrictions on opportunities for infant-industry protection imposed by the rules of the World Trade Organization; corrupt and weak governments at home; and an underlying lack of infrastructure that compounds the present comparative disadvantage in manufacturing that arises from the present resource ratios.

To start with the most fundamental issue: the last century has seen a transformation, albeit still continuing, in Africa's factor endowment: from a combination of land-abundance, increasing availability of unskilled labour, and a major growth in human capital formation. 
The aggregate population apparently started growing within a few years after the 1918 world influenza pandemic, and did so about six-fold by the end of the twentieth century. Though population density does not simply convert into labour abundance, in the long run the population explosion exerted downward pressure on African wages relative to wages outside Africa. At the time of the post-independence experiments in import-substitution industrialization, most of Africa was still labour-scarce and labour costs remained high compared to Asia. The most likely exception would have been the southern African settler states, South Africa and Rhodesia, where much of the rural male population had long been pressured into migrant labour. Even there, though manufacturing continued to expand in the 1950s and 1960s, it was behind protectionist tariffs. By the end of the twentieth century, however, the shift in factor ratios had reached the point where it was beginning to be surprising that, for instance, Ghana's labour costs in textiles were still too high to permit exports (Teal 1999). By the time of writing, wages in China have begun to overtake those in Africa and the Ethiopian government, by setting a legal minimum wage well below those of China, Indonesia and India, as well as African competitors, seems to be signalling a determination to make that cost advantage count. It is probably no coincidence that Ethiopia has begun to attract Chinese and Indian investment in manufacturing (Austin, Frankema and Jerven 2015: 26). ${ }^{8}$ By the same token, one can hope (regarding Onoge's point above) that labour repression is no longer necessary for industrialization, when real wages are already relatively low, and contracts all too precarious. Again, African workforces are much more widely and deeply educated than 50-60 years ago. Arguably the biggest achievement of the era of state-led development policy was the expansion of formal education at all levels (Sender 1999). Adult literacy had reached 56.1\% for women and 74.5\% for men in 2009 (World Bank 2013: Table 1): low compared to contemporary Asia, but well above the threshold for countries successfully industrializing in the past. In the context of cheaper and better educated labour, the prospect of the 'flying geese' of investment in labour-intensive manufacturing reaching Africa becomes much more realistic.

It should be noted that both the demographic and educational expansions were in part endogenous to the 'land extensive' path of development. Labour being scarce, high fertility was socially prized: enabling the (in these terms) exogenous decline in the mortality rate from the middle colonial period onwards to be quickly converted into rapid population growth (Iliffe 1989). Again, cash-cropping farmers invested their savings, above all, in school fees: whether to attend mission schools during the colonial period or the expanded state school system afterwards.

The immediate international threat to this prospect is less the WTO rules, which allow some leeway for newcomers, than a continuation of the current Chinese slow-down, which would limit potential export markets and perhaps also further inward investment. Moreover, since the Great Recession of 2008 the IMF and World Bank have become more markedly more concerned with market failures and more sympathetic to state intervention to counteract them. Two recent holders of the position of chief economist at the World Bank are among a group of former or current bank economists arguing very forcefully for state promotion of industrialization in Africa (Stiglitz, Lin, Monga and Patel 2013).

Again, while states in Africa remain relatively short of fiscal and administrative capacity, they have been potentially strengthened by the combination of economic growth and a larger supply of well-educated personnel. Central government expenditure in Sub-Saharan Africa has remained very consistent, at about 22\%, since the decade in which Structural Adjustment was introduced, despite the rather fast growth of GDP since 1995 (Table 1). This

\footnotetext{
${ }^{8}$ I owe this point to Ewout Frankema.
} 
suggests that, should larger budgets be needed, there is some room for expansion from internal revenue rather than necessarily from external loans or grant aid.

Table 1.Central Government Expenditure in Sub-Saharan Africa, 1980-2010

\begin{tabular}{|l|l|l|l|}
\hline Years & $\begin{array}{l}\text { Gross gov't fixed } \\
\text { capital formation }\end{array}$ & $\begin{array}{l}\text { Central government } \\
\text { final consumption }\end{array}$ & Total \\
\hline $1980-89$ & 6.1 & 16.5 & 22.6 \\
\hline $1990-99$ & 4.7 & 16.7 & 21.4 \\
\hline $2000-10$ & 5.9 & 16.4 & 22.3 \\
\cline { 2 - 4 }
\end{tabular}

Source: World Bank (2013): tables 2.15, 2.20.

Government spending on what? Joseph Stiglitz, Justin Lin and their colleagues envisage two priorities for industrial policy in contemporary Africa: encouraging the transfer of labour and other resources from low to high productivity sectors, 'including the migration of Africa's abundant unskilled rural labor to unskilled labor-intensive industries'; and further investment in education and learning, to improve the skills and adaptability of the workforce (Stiglitz, Lin, Monga and Patel 2013: 12). The movement out of agriculture is already largescale in most of Africa, as is visible in the accelerated urbanization of the last twenty years. The problem is insufficient employment. While labour-intensive industries can help, the comparative history of labour-intensive industrialization underlines the importance of enhancing skills if the process is to continue, and thereby contribute to rising output per capita rather than simply absorb the unemployed (Austin and Sugihara 2013). This perspective reinforces the case for further investment in education.

So does the ultimate fate of the apartheid economy. The last fifteen years before the regime handed over power in 1994 was a period of economic stagnation. While the slump was reinforced by the township revolt and the resultant loss of investor confidence, and eventually also by sanctions, arguably the initial and underlying cause was built into institutions and practice of apartheid itself. The same system that generated cheap unskilled labour made skilled labour artificially expensive: which imposed rising costs as the economy reached the limits of extensive growth, thereby increasingly needing TFP growth to maintain overall expansion. Already from 1967, well before the international oil price shock of 1973, the marginal efficiency of investment was in decline, gradually then rapidly (Lewis 1990: 132-3).

Along with education, investment in physical infrastructure, especially transport and electricity supply, is fundamental to the prospects of industrialization in Africa. Entrepreneurs in much of Africa (in Nigeria, notoriously) need their own generators, reflecting a gross lack of supply of an elementary public good. In addition, there will remain cases where governments can find useful ways to support specific industries: though each case has its own technical, economic and political complexities (Cramer 1999).

Relatedly, though not necessarily very expensively, African states may need to do more to help private firms develop the skills necessary to grow. So far, in most African countries, indigenous enterprises have rarely grown big - though there are notable exceptions, such as the conglomerate created by the Nigerian entrepreneur M. K. Abiola (1937-98). Mostly, where firms did not originate as a foreign or public enterprise sold to private African interests via the mediation of the state, they have been born small and remained fairly small, partly because few survive the death of their founder (Iliffe 1983: 74-5). This is especially important because there is evidence that the larger firms are the most likely to export (Rankin, Söderbom and Teal 2006).

Much of the literature is deeply sceptical about the developmental commitment of African ruling elites, given the primacy of patrimonial politics, and the frequent allegations of corruption over the years in many African states. In this context it has been argued that, far 
from Structural Adjustment solving the problem by cutting the state to a minimum and allowing the market to rule, 'adjustment' was captured by the elites, who used the aid to refuel their patronage networks, while avoiding serious implementation of the reforms (Chabal and Daloz 1999: 119-23). But it is a mistake to dismiss the seriousness with which some of the independence leaders - backed by mass demands for higher living standards, schools and better public health - approached development: missing the targets does not mean that the targets were not real. In the early 1980s, the dominant argument in rational-choice political science was that in Africa the incentives to leaders were radically un-aligned with the interests of the population as a whole, such that economic stagnation or even absolute decline was a price that a leader would rationally accept in order to reward his followers (Bates 1981). But, while this might apply to slow or even no growth, only if time-horizons were reduced to months would it make sense for a patron to worry only about sharing the cake, and not at all about enlarging it. The left-populist 'revolutionary' government of J. J. Rawlings, in Ghana in 1983, actually reversed its economic strategy - by adopting Structural Adjustment - when the initial policy led only to further shrinkage in output, and government revenue (Austin 1996a). Again, while economic liberalization certainly did not end patrimonialism and rent-seeking (and, as elsewhere in the world, privitizations provided a feast for rent-seekers), the economic reforms were implemented to a great extent: as the floating currencies and massive inflows of remittances illustrate. What is clear is that analysts need to take the nuances and details of politics seriously. In this vein, from a study of a number of recent country cases, Tim Kelsall (2011) has argued persuasively that where 'rent management can be centralised and oriented to the long term, neo-patrimonialism . . . can be harnessed for developmental ends'. As he notes, genuine electoral competition may divert politicians' priorities from the long-term (Kelsall 2011: 84): leaving greater scope for optimism about the economic future in de facto single-party systems such as Rwanda and Ethiopia. On the other hand, states in which power seems now more or less to alternate through the ballot box, such as Ghana, may eventually be the most effective in deterring corruption: if incumbents will not allow each other to be brought before a court (Ofori-Mensah 2009), the next ruling party will be ready to see their predecessors exposed. It could be suggested that, in the East Asian industrializations of the Cold War era, the tendencies towards corruption and rent-seeking (which were real) were kept in check by the existential threat from Communist neighbours. There was no very close analogy to this in Africa. Even so, while the pessimistic views are not without foundation, to see the 'African developmental state' as a contradiction in terms would be to go far beyond reason and evidence (Mkandawire 2001).

\section{Conclusions}

This paper has briefly reviewed Africa's developmental history in relation to the question of its chances of achieving a twenty-first century 'late industrialization'. This issue, and the insights of the Gerschenkron-Amsden tradition, need to be seen in a broader framework than that of deviations from the original, unplanned industrialization. Sugihara's notion of longterm 'paths' of economic development, responding to an original factor endowment with sequences of choices of technique and institution, provides a non-Eurocentric and less teleological approach. I have emphasised that the human responses themselves gradually or eventually change the so-called 'endowment'.

Until (often well into) the twentieth century (at least), Sub-Saharan Africa was characterized by a relative abundance of land and a relative scarcity of labour as well as capital. But obstacles to the intensive use of land - partly diminished over time by innovations including the selective adoption of exotic crops - meant that the region was mostly not 
'resource rich', at least not before industrialization elsewhere created or expanded export markets for various deposits that lay beneath Africa's soils and seas. These circumstances hindered, without preventing, state building before and, indeed, during and since colonial rule. They also favoured a 'land-extensive' path of development, especially in relation to cultivation and pastoralism, with a preference for maximizing returns to labour (without the environmental constraints) rather than to the abundant factor of land. As a result, though food security and probably real incomes gradually (if unevenly) improved over the centuries, African states were not in a position, economically or politically, to respond to the challenge of Western industrialization by launching, Meiji-style, a 'late industrialization'.

Factor endowments and African responses to them also help explain why Africa, especially West Africa, moved during the nineteenth and early twentieth centuries from handicraft manufacturing to primary-product exporting rather than directly to modern manufacturing. Colonial regimes reinforced rather than originated this, and the success of agricultural exporting, by land-extensive methods in what was still a labour-scarce economy, raised labour productivity and real wages in West Africa. Ironically, this did not help industrial competitiveness when modern manufacturing finally expanded across the continent, as Independence approached, and especially during the following phase of import-substitution industrialization policies, in the 1960s and 1970s.

Whereas 'regular' colonial administrations showed either no, or little and late, interest in promoting manufacturing, the self-governing settler regimes of South Africa and Southern Rhodesia embarked on import-substitution industrialization as early as the 1920s and 1930s, respectively, using the revenues and import-purchasing power derived from their mineral wealth. The growth of their mining, and then also the manufacturing sectors, was crucially facilitated by the success of the state in driving down the real wages of unskilled labourers, through drastically reducing Africans' access to land in order to oblige them to sell their labour. These were 'developmental states', albeit only in the narrowest sense: unrelated (or inversely related) to the welfare of the vast majority of the populations. The ultradiscriminatory labour policy on which the growth of the apartheid economy initially relied, however, proved self-limiting: in the in the 1980s and early 1990s the South African economy was becalmed, primarily because the cheapness of unskilled labour went along with a scarcity premium for skilled workers. The latter cost greatly inhibited South African manufacturing when it needed to move on from essentially extensive growth to partly intensive, TFP-based expansion.

Meanwhile, further north the 1960s-70s experiments of most newly-independent tropical African states with import-substitution industrialization had yielded mostly modest economic growth, the states which did best being those which sought to diversify around primary exports, rather than to over-tax the latter in the hope of making infant industries thrive. The liberal economic regimes that were inaugurated in the 1980s are still with us. With a few exceptions, they saw little or negative economic growth until 1995, since when the GDP of Sub-Saharan Africa has been outpacing population growth by about $2 \%$ a year. But, with industrialization off the agenda, manufacturing has actually receded as a share of total output since 1980.

There is currently renewed enthusiasm for state promotion of manufacturing in policy circles, including at the World Bank. What makes this more realistic than the ambitions of the import-substitution era is that resource ratios have become much more favourable. The nonsettler states of late twentieth-century Africa invested heavily in spreading education, helped by the willingness of cash-crop farmers and labourers to pay school fees. Meanwhile, much of Africa is well advanced in a transition to labour-abundance, thanks to a twentieth-century population explosion that was facilitated by the high social approval of high fertility, which was an institutional component of the land-extensive path of development. 
Reflecting on this story so far, the eventual demise of the apartheid route to industrialization is consistent with the emphasis on the importance of human capital formation in the 'broad capital' strand of endogenous growth theory. The other strand of the theory, focussed on the sources of TFP growth, is much less relevant to the growth of modern manufacturing in Africa, to date and in the likely near future, because the case fits Amsden's definition of 'late industrialization' as using borrowed technology. Amsden's dismissal of the competitive importance of cheap unskilled labour, on the other hand, does not fit the growth of South African output, including manufacturing, as late as the 1970s. It also seems to understate the value of cheap labour in contemporary international rivalry in textiles and other relatively labour-intensive industries.

Gerschenkron and Amsden's identification of the state as the organizing 'substitute' for the market in the most 'backward' economies was shared by the settler states of twentiethcentury Africa, and by the governments of the newly-independent governments in the 1960s. Though the results of state-led development strategies in the 1960s and 1970s were pretty limited, it is inescapable that the state is the key agent for orchestrating any renewed manufacturing drive in the foreseeable future. Not least, this is because of the comparative paucity of large private African companies, South Africa excepted.

Perhaps the biggest difference between 'late development' in Africa from

Gerschenkron's analysis of 'substitutions' in the context of 'relative backwardness' is the role of primary commodity exports. Gerschenkron emphasized the need for a market for industrial goods, which he considered to have been provided in Britain by rising labour productivity in agriculture. In the case of late nineteenth-century Russia, he believed that the state extracted sufficient surplus from a relatively low-productivity agricultural sector to enable it to provide both capital and demand for manufactures. By contrast, in Africa it was income from export agriculture and mining that created 'expanded' markets for industrial goods, and enabled first the settler regimes, and later the governments of the newly-independent rest of Africa, to subsidize import-substitution industrialization. Despite outbreaks of Dutch disease, notably in Nigeria after the 1983 OPEC oil price rise, any state push for industrialization in the near future is likely again to have to rely on revenue and import-purchasing power generated from primary exports.

Having seen India move from the so-called 'Hindu growth rate' to rapid 'late development' within recent decades, in principle it seems realistic to hope that Africa is not 'too late' for 'late industrialization'. Gerschenkron was right that the industrialization of even one country altered the conditions for future industrializations. The earlier industrializations provided technologies which - despite the restrictions of patent laws and WTO regulations African countries can hope to adopt, as they already have to some extent. They also enlarged or created the export markets for the primary commodities highlighted above. However, there is a formidable disadvantage of lateness, which Gerschenkron did not predict. If African countries are eventually unable to reach the average living standards of the currently industrialized countries, it is likely to be because of the combination of the environmental impact of global industrialization to date, with the measures needed to mitigate its longer-term effects (Austin, 2016b).

\section{References}

Abramovitz, Moses, and Paul A. David (1996), 'Convergence and deferred catch-up: productivity leadership and the waning of American exceptionalism', in Ralph Landau, Timothy Taylor and Gavin Wright (eds), The Mosaic of Economic Growth (Stanford: Stanford University Press), 21-62. 
Accominotti, Olivier, Marc Flandreau, Riad Rezzik, and Frédéric Zumer (2010). 'Black man’s burden, white man's welfare: control, devolution and development in the British empire, 1880-1914', European Review of Economic History 14:1, 47-70.

Acemoglu, Daron, Simon Johnson and James A. Robinson (2001), ‘The colonial origins of comparative development: an empirical investigation’, American Economic Review 91: 5, 1369-1401.

Acemoglu, Daron, Simon Johnson and James A. Robinson (2002), 'Reversal of fortune: geography and institutions in the making of the modern world income distribution', Quarterly Journal of Economics 117:4, 1231-79.

Acemoglu, Daron, and James A. Robinson (2012), Why Nations Fail: The Origins of Power, Prosperity, and Poverty (New York: Crown).

Amsden, Alice H. (1989), Asia's Next Giant: South Korea and Late Industrialization (Oxford: Oxford University Press).

Amsden, Alice H. (1992), 'A theory of government intervention in late industrialization', in Louis Putterman and Dietrich Rueschemeyer (eds), State and Market in Development: Synergy or Rivalry?, 53-84. Boulder: Lynne Reiner.

Amsden, Alice H. (2001), The Rise of 'The Rest': Challenges to the West from Late-Industrializing Economies (New York: Oxford University Press).

Austin, Gareth (1996a), 'National poverty and the "vampire state” in Ghana: a review article', Journal of International Development 8 (1996), 553-73.

Austin, Gareth (1996b), 'Mode of production or mode of cultivation: explaining the failure of European cocoa planters in competition with African farmers in colonial Ghana', in W.G. ClarenceSmith (ed.), Cocoa Pioneer Fronts Since 1800: the Role of Smallholders, Planters and Merchants (Basingstoke, UK: Macmillan), 154-75.

Austin, Gareth (2005), Labour, Land and Capital in Ghana: From Slavery to Free Labour in Asante, 1807-1956 (Rochester NY: University of Rochester Press).

Austin, Gareth (2008a), 'Resources, techniques and strategies south of the Sahara: revising the factor endowments perspective on African economic development, 1500-2000', Economic History Review, 61:3, 587-624.

Austin, Gareth (2008b), 'The "reversal of fortune” thesis and the compression of history: perspectives from African and comparative economic history', Journal of International Development, 20:8, 9961027.

Austin, Gareth (2010), 'The developmental state and labour-intensive industrialization: "late development” reconsidered’, Economic History of Developing Regions, 25:1, 51-74.

Austin, Gareth (2012), 'Developmental "paths” and “civilizations” in Africa and Asia: reflections on strategies for integrating cultural and material explanations of differential long-term economic performance', in Masahiko Aoki, Timur Kuran and Gérard Roland (eds), Institutions and Comparative Economic Development (Palgrave Macmillan; International Economics Association), 237-53.

Austin, Gareth (2013a), 'Labour-intensity and manufacturing in West Africa, c.1450-c.2000', in Gareth Austin and Kaoru Sugihara (eds), Labour-Intensive Industrialization in Global History (London: Routledge), 201-30. 
Austin, Gareth (2013b), 'Labour-intensive industrialization and global economic development: reflections', in Gareth Austin and Kaoru Sugihara (eds), Labour-Intensive Industrialization in Global History (London: Routledge), 280-302.

Austin, Gareth (forthcoming, 2016a), 'Slavery in Africa' in David Eltis, Stanley Engerman and David Richardson (eds), The Cambridge World History of Slavery, volume 4, Slavery Since 1804 (Cambridge: Cambridge University Press).

Austin, Gareth (forthcoming, 2016b), 'Africa and the Anthropocene', in Austin, ed., Economic Development and Environmental History in the Anthropocene: Perspectives on Asia and Africa (London: Bloomsbury Academic).

Austin, Gareth, Ewout Frankema and Morten Jerven (2015), 'Patterns of manufacturing growth in Sub-Saharan Africa: from colonization to the present', Utrecht: Working Paper 17, Centre for Global Economic History.

Gareth Austin and Kaoru Sugihara (eds) (2013), Labour-Intensive Industrialization in Global History (London: Routledge).

Bates, Robert H. (1990), 'Capital, kinship, and conflict: the structuring influence of capital in kinship societies’, Canadian Journal of African Studies 24:1, 145-64.

Bénétrix, Agustín S., Kevin H. O'Rourke, and Jeffrey G. Williamson (2012), 'The Spread of Manufacturing to the Periphery 1870-2007: Eight Stylized Facts', National Bureau of Economic Research Working Paper 18221, July 2012 (http://www.nber.org/papers/w18221)

Breman, Henk (2012), ““African soils are sooo ... fertile”, in Henk J. W. Mutsaers and Paul W. M. Kleene (eds), What is the Matter with African Agriculture? Veterans' Visions Between Past and Future (Amsterdam: KIT), 180-5.

Brett, E. A. (1973), Colonialism and Underdevelopment in East Africa: The Politics of Economic Change 1919-1939 (London: Heinemann).

Boone, Catherine (1992), Merchant Capital and the Roots of State Power in Senegal, 1930-1985 (Cambridge: Cambridge University Press).

Booth, Anne (2007), 'Night watchman, extractive, or developmental states? Some evidence from late colonial South-East Asia’, Economic History Review, 60:2, 241-66.

Bowden, Sue, Blessing Chiripanhura and Paul Mosley (2008), 'Measuring and explaining poverty in six African countries: a long-period approach', Journal of International Development, 20: 8 (2008), 1049-79.

Brown, Ian (1997), Economic Change in South-East Asia, c.1830-1980 (Oxford University Press).

Butler, L. J. (1997) Industrialisation and the British Colonial State: West Africa, 1939-1951 (London: Frank Cass).

Chabal, Patrick, and Jean-Pascal Daloz (1999), Africa Works: Disorder as Political Instrument (Oxford: James Currey).

Chang, Ha-Joon (2002), Kicking Away the Ladder: Development Strategy in Historical Perspective (London: Anthem Press). 
Clarke, Donald, Peter Murrell and Susan Whiting (2008), 'The role of law', in Loren Brandt and Thomas G. Rawski (eds), China’s Great Economic Transformation (New York: Cambridge University Press), 337-74.

Crafts, N. F. R. (1997), ‘Endogenous growth: lessons for and from economic history’, in David M. Kreps and Kenneth F. Wallis (eds), Advances in Economics and Econometrics: Theory and Applications - Seventh World Congress, vol. II (Cambridge: Cambridge University Press), 38-78.

Cramer, Christopher (1999), 'Can Africa industrialize by processing primary commodities? The case of Mozambican cashew nuts’, World Development, 27:7, 1247-66.

Crummey, Donald (1980), ‘Abyssinian feudalism’, Past and Present, 89: 115-38.

Dewey, Clive (1978), 'The end of the Imperialism of Free Trade: the eclipse of the Lancashire lobby and the concession of free trade to India', in Clive Dewey and A. G. Hopkins (eds), The Imperial Impact: Studies in the Economic History of Africa and India (London: Athlone Press for University of London), 35-67, 331-8.

Fahnbulleh, Miatta (2005), 'The Elusive Quest for Industrialisation in Africa: A Comparative Study of Ghana and Kenya, c1950-2000’ (London School of Economics: PhD dissertation).

Feinstein, C. H. (2005), Conquest, Discrimination and Development: an Economic History of South Africa (Cambridge: Cambridge University Press).

Frankema, Ewout (2010), 'Raising revenue in the British empire, 1870-1940: how "extractive” were colonial taxes?’, Journal of Global History, 5: 3 (447-77).

Frankema, Ewout, and Morten Jerven (2014), 'Writing history backwards or sideways: towards a consensus on African population, 1850-2010', Economic History Review, 67:4, 907-31.

Frankema, Ewout, and Marlous van Waijenburg (2012), 'Structural impediments to African growth? New evidence from real wages in British Africa, 1880-1965’, Journal of Economic History, 72.4, 895926.

Frankema, Ewout, and Marlous van Waijenburg (2014), 'Metropolitan blueprints of colonial taxation? Lessons from fiscal capacity building in British and French Africa, c.1880-1940', Journal of African History, 55:3, 371-400.

Gardner, Leigh A. (2012), Taxing Colonial Africa: The Political Economy of British Imperialism (Oxford: Oxford University Press).

Goody, Jack (1971), Tradition, Technology and the State in Africa (London: Oxford University Press for the International African Institute).

Goody, Jack (1976), Production and Reproduction: A Comparative Study of the Domestic Domain (Cambridge: Cambridge University Press).

Gerschenkron, Alexander (1962), Economic Backwardness in Historical Perspective (Cambridge MA: Harvard University Press).

Herbst, Jeffrey (2000), States and Power in Africa: Comparative Lessons in Authority and Control (Princeton: Princeton University Press, 2000).

Hill, Polly (1997), The Migrant Cocoa-Farmers of Southern Ghana, $2^{\text {nd }}$ edition with preface by Gareth Austin, Hamburg: LIT ( $1^{\text {st }}$ edition Cambridge University Press, 1963). 
Hopkins (1973), An Economic History of West Africa (London: Longman).

Hopkins, A. G. (1978), 'Innovation in a colonial context: African origins of the Nigerian cocoafarming industry, 1880-1920', in Clive Dewey and A. G. Hopkins (eds), The Imperial Impact (London: Athlone Press for University of London), 83-96, 341-2.

Inikori, Joseph E. (2003), 'The struggle against the transatlantic slave trade: the role of the state', in Sylviane A. Diouf (ed.), Fighting the Slave Trade: West African Strategies (Athens OH), 170-98.

Inikori, Joseph E. (2007), 'Africa and the globalization process: western Africa, 1450-1850', Journal of Global History 2:1, 63-86.

Iliffe, John (1983), The Emergence of African Capitalism (London: Macmillan).

Iliffe, John (1989), ‘The origins of African population growth', Journal of African History 30:1, 1659 .

IPCC (Intergovernmental Panel on Climate Change) (2014), 'Summary for policymakers', in Climate Change 2014: Impacts, Adaptation, and Vulnerability (Cambridge: Cambridge University Press), 132.

Kelsall, Tim (2011), 'Rethinking the relationship between neo-patrimonialism and economic development in Africa', IDS Bulletin, 42:2, 76-86.

Kilby, Peter (1975), 'Manufacturing in colonial Africa', in Peter Duignan and L. H. Gann (eds), Colonialism in Africa, 1870-1960, vol. IV, The Economics of Colonialism (Cambridge: Cambridge University Press), 475-520.

Kirk-Greene, A. H. M. (1980), 'The Thin White Line: the Size of the British Colonial Service in Africa', African Affairs 79: 314, 25-44.

Law, Robin (1978), 'Slaves, trade, and taxes: the material basis of political power in nineteenthcentury West Africa’, Research in Economic Anthropology 1, 37-52.

Law, Robin (1995), (ed.), From Slave Trade to 'Legitimate' Commerce: the Commercial Transition in Nineteenth-century West Africa (Cambridge: Cambridge University Press).

Lewis, S. R., jr. (1990), The Economics of Apartheid (New York: Council on Foreign Relations).

Lipton, Merle (1986), Capitalism and Apartheid: South Africa, 1910-84 (Aldershot: Gower).

Lovejoy, Paul E. (2012), Transformations in Slavery: A History of Slavery in Africa, $3^{\text {rd }}$ edition (New York: Cambridge University Press).

Manning, Patrick (1990), Slavery and African Life: Occidental, Oriental, and African Slave Trades (Cambridge: Cambridge University Press).

Manning, Patrick (2010), ‘African population projections, 1850-1960’, in Karl Ittmann, Dennis D.

Cordell, and Gregory H. Maddox (eds), The Demographics of Empire: the Colonial Order and the Creation of Knowledge, 245-75, Athens, Ohio: Ohio University Press.

Mkandawire, Thandika (2001), 'Thinking about developmental states in Africa', Cambridge Journal of Economics, 25:3, 289-313.

Mokwunye, U., and A. Bationo (2002), 'Meeting the phosphorus needs of the soils and crops of West Africa: the role of indigenous phosphate rocks', in B. Vanlauwe, J. Djiels, N. Sanginga and R. Merckx 
(eds), Integrated Plant Nutrient Management in Sub-Saharan Africa: From Concept to Practice, (Wallingford, Oxfordshire, UK: CABI Publishing and the International Institute of Tropical Agriculture), 209-24.

Mytelka, L. K. (1989), 'The unfulfilled promise of African industrialization', African Studies Review, 32:3, 77-137.

North, Douglass C. (1990), Institutions, Institutional Change and Economic Performance (New York: Cambridge University Press).

Ofori-Mensah, Michael (2009), 'The Politics of Anticorruption in Ghana, 1993-2006: Action, Inaction and Accountability' (University of Edinburgh: PhD dissertation).

Phimister, I. (2000), 'The origins and development of manufacturing in Southern Rhodesia, 18801939' and 'From preference towards protection: manufacturing in Southern Rhodesia, 1940-1965', in A. S. Mlambo, E. S. Pangeti, and I. Phimister (eds), Zimbabwe: A History of Manufacturing, 18901995 (Harare: University of Zimbabwe Publications), 9-50.

Rankin, Neil, Måns Söderbom and Francis Teal (2006), 'Exporting from manufacturing firms in SubSaharan Africa’, Journal of African Economies, 15:4, 671-87.

Roberts, Richard L. (1996), Two Worlds of Cotton: Colonialism and the Regional Economy in the French Soudan, 1800-1946. Stanford: Stanford University Press.

Schrank, Andrew (forthcoming, 2015), 'Toward a new economic sociology of development', Sociology of Development.

Sender, John (1999), ‘Africa’s economic performance: limitations of the current consensus', Journal of Economic Perspectives 13: 3, 89-114.

Sender, John and Sheila Smith. The Development of Capitalism in Africa (London, 1986).

Stiglitz, Joseph, Justin Lin, Célestin Monga and Ebrahim Patel (2013), 'Industrial Policy in the African Context’ (Washington DC: World Bank Policy Research Working Paper 6633).

Sugihara, Kaoru (2003), 'The East Asian path of development: a long-term perspective', in Giovanni Arrighi, Takeshi Hamashita and Mark Seldon (eds), The Resurgence of East Asia: 500, 150 and 50 Year Perspectives (London: Routledge), 78-123.

Sugihara, Kaoru (2007), 'The second Noel Butlin lecture: labour-intensive industrialisation in global history’, Australian Economic History Review, 47:2, 121-54.

Sugihara, Kaoru (2013), 'Labour-intensive industrialization in global history: an interpretation of East Asian experiences', in Gareth Austin and Kaoru Sugihara (eds), Labour-Intensive Industrialization in Global History (London: Routledge), 20-64.

Teal, Francis (1999), 'Why can Mauritius export manufactures and Ghana not?’, The World Economy, 22: 7, 981-93.

Trapido, Stanley (1971), 'South Africa in a comparative study of industrialisation', Journal of Development Studies, 7:3, 309-20.

United Nations Economic Commission for Africa (2013), Making the Most of Africa's Commodities: Industrializing for Growth, Jobs and Economic Transformation: Economic Report on Africa 2013 (Addis Ababa).

Van der Linden, Marcel (2012), 'Gerschenkron’s secret: a research note’, Critique: Journal of Socialist Theory, 40:4, 553-62. 
Vanlauwe, B., J. Djiels, N. Sanginga and R. Merckx (eds) (2002), Integrated Plant Nutrient Management in Sub-Saharan Africa: From Concept to Practice (Wallingford, Oxfordshire, UK: CABI Publishing and the International Institute of Tropical Agriculture).

Wade, Robert (1990), Governing the Market: Economic Theory and the Role of Government in Industrialization (Princeton: Princeton University Press).

World Bank (1981), Accelerated Development in Sub-Saharan Africa: An Agenda for Action (Washington DC: World Bank).

World Bank (2013), African Development Indicators (Washington DC: World Bank). 